\section{A Novel Source of Resistance to Pepper yellow leaf curl Thailand virus (PepYLCThV) (Begomovirus) in Chile Pepper}

\author{
Derek W. Barchenger \\ World Vegetable Center, Shanhua, Tainan, Taiwan
}

Sopana Yule

World Vegetable Center East and Southeast Asia Research and Training

Station, Kamphaeng Saen, Nakhon Pathom, Thailand

Nakarin Jeeatid

Horticulture Section, Department of Plant Science and Agricultural Resources, Plant Breeding Research Center for Sustainable Agriculture Faculty of Agriculture, Khon Kaen University, Khon Kaen, Thailand

Shih-wen Lin, Yen-wei Wang, Tsung-han Lin, Yuan-li Chan, and Lawrence Kenyon

World Vegetable Center, Shanhua, Tainan, Taiwan

Additional index words. Bemisia tabaci, Capsicum annuum, Geminiviridae, host resistance

Abstract. Chile pepper (Capsicum annuum L.) is an increasingly important vegetable and spice crop. Among the most devastating chile pepper-infecting viruses, especially in tropical and subtropical regions, are members of the whitefly transmitted Begomovirus, which cause pepper yellow leaf curl (PYLC). An effective PYLC management strategy is the development of resistant cultivars. However, genetic recombination, acquisition of extra DNA components, and synergistic interactions among different begomoviruses have resulted in the rapid emergence of new viruses that can infect new hosts, cause new disease symptoms, and overcome host resistance. In this project, 98 Capsicum entries comprising breeding lines, open pollinated varieties, genebank accessions, and wild species were screened for resistance to strains of Pepper yellow leaf curl Thailand virus (PepYLCThV). We used a randomized complete block design with three replications and 10 plants per replication in field net-houses at two locations (Khon Kaen and Kamphaeng Saen, Thailand) using augmented inoculation by viruliferous whiteflies. Scoring was done at $\approx 60,90$, and 120 days after inoculation using a standardized 6-point scale $(1=$ no symptoms to 6 = very severe symptoms), and the average of the scores of 10 plants within each replication was used for analysis. Although no entry was immune to the disease, the breeding line 9852-123 was highly resistant. Several accessions and lines were moderately resistant at both locations, although a high level of variability within these entries was observed. Overall, the disease severity at the Khon Kaen location was greater compared with Kamphaeng Saen, highlighting the importance of multilocation testing for disease resistance. The resistant entry identified here can be used to study gene action and to move resistance genes into well-adapted germplasm.

Chile pepper (Capsicum annuum L.) is widely used as a vegetable and spice and a source of colorants and pharmaceuticals (Wall and Bosland, 1998). Consumer demand for chile pepper has substantially increased over the past 30 years, especially for hot pepper. It has been estimated that chile peppers are consumed daily by approximately a quarter of the world's population (Halikowski-Smith, 2015). Global production of chile pepper was 56.2 million tonnes on an area of 4.5 million hectares in 2016 and $\approx 65 \%$ of chile pepper was produced in Asia (Food and Agriculture Organization of the United Nations, 2016). Being a high value crop (DeWitt and Bosland, 1993), chile pepper can have economic benefits for small-

holder farmers, significantly increasing family income and socioeconomic mobility (Kahane et al., 2013; Weinberger and Lumpkin, 2007).

The primary limitations to increased chile pepper productivity and quality are biotic and abiotic stresses. In addition to consumer demand for chile pepper, the past 3 decades have seen the number of virus species identified as infecting chile pepper as well as virus disease incidence increase considerably (Kenyon et al., 2014b). Likely, the most devastating chile pepper-infecting viruses, especially in tropical and subtropical regions of Asia, are members of the whitefly (Bemisia tabaci)-transmitted genus Begomovirus (Geminiviridae), including PepYLCThV. Unlike in tomato (Solanum lycopersicum), the emergence of begomoviruses as major chile pepper pathogens has been relatively recent. Pernezny et al. (2003) reported five begomoviruses causing disease in chile pepper in the Americas and only one in Asia. Since then, the number of chile pepper-infecting begomoviruses detected in Asia has greatly increased, with at least 29 species and a large diversity of strains reported (Kenyon et al., 2018). Although Pepper yellow leaf curl virus (PepYLCV) was first identified in Thailand in 1995 (Samretwanich et al., 2000), PepYLCThV was not identified in Thailand until 2012 (Chiemsombat et al., 2018), and the sequences of both DNA-A and DNA-B components were submitted to National Center for Biotechnology Information in 2016. Across Thailand, PYLC is caused by at least three bipartite Begomovirus species, with a common PepYLCThV DNA-B component, and sometimes as mixed infections (Chiemsombat et al., 2018). In some of the hotspots for the disease, losses of $95 \%$ have been reported, and farmers have been forced to grow alternative crops.

Management of begomoviruses has been based primarily on insecticides against the whitefly vector. However, the use of insecticides has been found to be only partially effective, costly for producers, and represents a hazard to farmers, consumers, and the environment (Borah and Dasgupta, 2012), while limiting export potential through presence of pesticide residue. Farmers often apply the insecticides after seeing early disease symptoms, by which time the whiteflies have already transmitted the virus to other plants (Kenyon et al., 2014a). An effective alternative to harmful insecticide applications for management of Begomovirus is the development of resistant cultivars (Shankarappa et al., 2008).

Sources of resistance to Begomovirus in chile pepper have been reported, including the $C$. chinense line BG-3821 in Mexico (Anaya-Lopez et al., 2003) and 'Bhut Jolokia' in India (Adluri et al., 2017). The C. annuum lines DLS-Sel-10, WBC-Sel-5, WorldVeg Pepper Breeding Collection (PBC) 142, PBC 145, PBC 345 (Srivastava et al., 2015, 2017), PBC 143, PBC 144, PBC 149, PBC 495, VI012005 (Kenyon et al., 2014a), GKC-29, BS-35, EC-497636 (Kumar et al., 2006), and 'Kalyanpur Chanchal' (Singh et al., 2016) have been reported to be resistant. However, many of these screenings were done several years ago, and the pathogen population most likely has changed since then (Singh et al., 2016) from largely monopartite to bipartite species; therefore, confirmation of resistance with recently developed virus species is required.

\section{Materials and Methods}

The experiment was conducted at two locations, Khon Kaen (lat. $16.469^{\circ} \mathrm{N}$, long. $102.813^{\circ} \mathrm{E}$; elevation $162 \mathrm{~m}$ ) and Kamphaeng Saen (lat. $14.029^{\circ} \mathrm{N}$, long. $99.964^{\circ} \mathrm{E}$; elevation $9 \mathrm{~m}$ ), Thailand. Site selection was based on the ability to conduct an effective bioassay, rather than on nearby 
production or viral prevalence. Capsicum entries (98) comprising breeding lines, open pollinated varieties, genebank accessions, and wild species were screened for resistance to PepYLCThV. Among the 98 entries tested, two (PI 574547 and PI 674459) were members of the wild progenitor C. annuum var. glabriusculum, four (VI012478, VI102479, VI012528, and VI014924) were C. baccatum, 14 (PBC 206, PBC 506, PI 152225, PI 164561, PI 159234, PI 159236, PI 175622, VI012270, VI012271, VI012596, VI012642, VI012665, VI012668, and VI029244) were C. chinense, one (PI 566812) was C. chacoense, one (PBC 687) was $C$. frutescens, and the rest (76) were C. annuиm. Selection of entries for screening was based on resistance reported in publications (Adluri et al., 2017; Kenyon et al., 2014a; Srivastava et al., 2015, 2017), historical breeding notes, and personal communications with private and public sector plant breeders working with the disease.

Seeds of the entries were sown into a commercial coconut coir and peatmoss seedling media in 96-cell plastic trays at a rate of three seeds per cell per entry. Seeds were sown into 32 cells. The growing media was monitored for moisture twice daily and hand irrigated as needed. Seeds were germinated and seedlings grown in an insect-proof net house where virus vectors (whiteflies, aphids, thrips) were excluded. Seedlings were fertilized as needed, usually once a week after the first 2 weeks. Throughout the first 3 weeks, germination was closely monitored, and entries with slow germination or poor growth were resown as needed. Plants were thinned to one seedling per cell, and some were transplanted into empty cells to ensure a minimum of 30 plants per entry.

Augmented inoculation by viruliferous whitefly was used. Whitefly were reared and multiplied on broccoli (Brassica oleracea var. italica Plenck) plants, a nonhost. To prepare the virus source plants for the experiments, clean, healthy whiteflies were given a 48-h acquisition access period (AAP) on initial source plants infected with PepYLCThV

Received for publication 20 Aug. 2019. Accepted for publication 23 Sept. 2019.

Funding for this research was provided by the WorldVeg Innovation Funds and long-term strategic donors to the World Vegetable Center, Republic of China (Taiwan); UK aid from the UK government; U.S. Agency for International Development (USAID); Australian Centre for International Agricultural Research (ACIAR), Germany, Thailand, Philippines, Korea, and Japan. We thank Mr. Mongkol Sratongjun and Dr. Jutharat Chuapong of East West Seed for providing the isolate used at Kamphaeng Saen and for sequencing the virus.

Current address for N.J.: Department of Plant and Soil Sciences, Faculty of Agriculture, Chiang Mai University, Chiang Mai, Thailand.

D.W.B. is the corresponding author. E-mail: derek. barchenger@worldveg.org.

This is an open access article distributed under the CC BY-NC-ND license (https://creativecommons. org/licenses/by-nc-nd/4.0/).
Kanchanaburi isolate (provided by East West Seed for the Kamphaeng Saen location) and with PepYLCThV KON-KG5 isolate (for the Khon Kaen location). The two isolates of PepYLCThV used in this experiment were phylogenetically similar to one another, and both resulted in typical leaf yellowing and curling (Chiemsombat et al., 2018; Sangsotkaew et al., 2019). Presence of the single isolates in the source plants was confirmed by collecting and drying leaf tissue, isolating DNA from the leaf tissue using Dellaporta extraction method. The universal begomovirus primer pair PAL1v1978B/PAR1c715H and the primers DNABLC1, DNABLC2, and DNABLV2 were used to test for the presence of DNAA and DNA-B, respectively (Tsai et al., 2011). The amplicons were sequenced and aligned, and the viral DNA was classified based on sequence similarity to previously reported species. After the AAP, the viruliferous whiteflies were released on 5-weekold susceptible chile pepper ('Jindadang'; 20 whiteflies per plant) for an inoculation access period (IAP) of $48 \mathrm{~h}$ inside cotton bags. The PepYLCThV-inoculated plants were maintained in insect-proof cages until typical symptoms of leaf vein yellowing and curling developed. When the seedlings of the test lines and entries reached the four to six leaf stage $(\approx 4$ weeks), they were randomly placed in an insect-proof cage (90 mesh) at a rate of 12 trays per cage, and the PepYLCThV source plants and viruliferous whiteflies were introduced with one source plant for every two trays and 60 viruliferous whiteflies per source plant. Source plants were hand-agitated twice daily to encourage viruliferous whiteflies to move between source plants and test plants. After $10 \mathrm{~d}$, source plants were removed from the cage, and plants were directly transplanted to the field net houses. To increase virus infection stress, 500 healthy whiteflies and 800 viruliferous whiteflies per net house were released after transplanting, at Kamphaeng Saen. After 2 weeks, biweekly scouting and insecticide applications were made to manage insect vectors (whitefly, thrips, and aphids) and limit contamination from other pathogens.

Scoring was done at $\approx 60,90$, and $120 \mathrm{~d}$ postinoculation (dpi). A standardized 6-point scale modified from Sangsotkaew et al. (2019) $(1=$ no symptoms; 2 = very mild symptoms with slight yellowing only occurring near the petiole of young leaves; $3=$ mild symptoms of slight yellowing of the entire area of young leaves; $4=$ moderate symptoms of dark yellowing of young leaves and some old leaves; $5=$ severe symptoms of dark yellowing of young and most of the old leaves; $6=$ very severe symptoms of complete plant yellowing, stunting, and lack of flower set) was used for evaluation. The experimental design was a randomized complete block design with three replications and 10 plants of each entry in each replication. The average of the score of 10 plants within each replication was used for analysis. Data were analyzed for independence using the Kruskal-Wallis test in $\mathrm{R}$.

To determine the presence of nontarget viruses, five to 10 leaves from 12 randomly selected plants with typical and atypical PepYLCThV symptoms were collected and rapidly dried using self-indicating silica gel at ambient temperature 90 dpi. DNA was isolated from the leaf tissue using Dellaporta extraction method. The DNA was subjected to polymerase chain reaction (PCR) using universal Begomovirus primers as described earlier. To test for the presence of Cucumber mosaic virus, Potato virus $Y$, Tomato mosaic virus, Chili veinal mottle virus, Pepper veinal mottle virus, Pepper mild mottle virus, Tomato spotted wilt virus, Watermelon silver mottle virus, Pepper mottle virus, and nonspecific Potyvirus, crude sample homogenate $(1: 10 \mathrm{w} / \mathrm{v})$ was subjected to double- or tripleantibody-sandwich enzyme-linked immunosorbent assay (ELISA) with appropriate proprietary antisera. To detect the presence of unspecified Tospovirus and Polerovirus, total RNA was extracted and subjected to reverse transcriptase (RT)-PCR using universal primers of Tospovirus and Polerovirus, respectively.

After $120 \mathrm{dpi}$, leaf tissue from 10 symptomatic and asymptomatic plants of the highly resistant breeding line 9852-123 were collected and dried following the aforementioned procedure. The DNA was subjected to PCR using universal Begomovirus primers (Tsai et al., 2011), and amplicons were sequenced. The sequences were aligned, and the viral DNA was classified on the basis of sequence similarity to previously reported species.

\section{Results and Discussion}

One sample from a plant of PBC 351 tested positive for presence of Tospovirus RNA by RT-PCR, indicating infection by thrips transmission occurred during the experiment. However, symptoms typical of Tospovirus were minimal throughout the experimental plots; no other tested sample contained Tospovirus or any other tested viral RNA, and none tested positive by ELISA for other viruses. This suggests that the experiment was valid and the disease ratings for PepYLCThV were not confounded with symptoms of other viruses.

The Kruskal-Wallis test by ranks ( $\alpha=0.05$ ) indicated that average disease ratings at $120 \mathrm{dpi}$ across the 98 entries and at the two locations tested were nonidentical (Table 1). The average disease rating increased throughout the growing

Table 1. Kruskal-Wallis test by ranks of the diseases ratings of 98 Capsicum entries at 120 d postinoculation with Pepper yellow leaf curl Thailand virus at two locations (Kamphaeng Saen and Khon Kaen, Thailand).

\begin{tabular}{lcrc}
\hline & $\begin{array}{c}\text { Degrees of } \\
\text { freedom }\end{array}$ & \multicolumn{1}{c}{$\chi^{2}$} & $P$ value \\
\hline Location & 1 & 6.2 & 0.0128 \\
Replication & 2 & 17.1 & 0.0002 \\
Entry & 97 & 193.9 & $1.921 \times 10^{8}$ \\
\hline
\end{tabular}




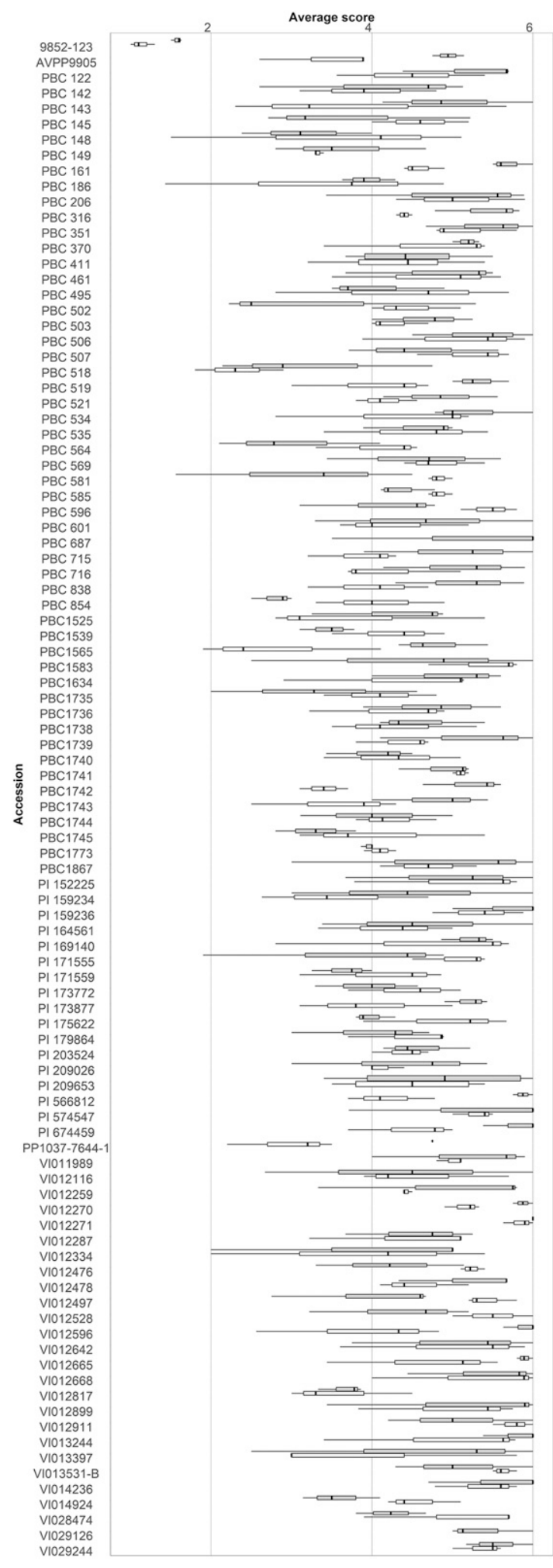

Fig. 1. Average disease rating of 98 Capsicum entries at $120 \mathrm{~d}$ postinoculation with Pepper yellow leaf curl Thailand virus. Scores were averaged across three replications each with 10 plants within a location. The white boxes are the lower and upper quartiles of the scores from Kamphaeng Saen, and the gray boxes are the lower and upper quartiles of the scores from Khon Kaen. The dark line within each box is the overall mean for the entry at each location, and the whiskers represent the overall maximum and minimum scores. A standardized six-point scale modified from Sangsotkaew et al. (2019) $(1=$ no symptoms; 2 = very mild symptoms with slight yellowing only occurring near the petiole of young leaves; 3 = mild symptoms of slight yellowing of the entire area of young leaves; $4=$ moderate symptoms of dark yellowing of young leaves and some old leaves; $5=$ severe symptoms of dark yellowing of young and most of the old leaves; $6=$ very severe symptoms of complete plant yellowing, stunting, and lack of flower set) was used for evaluation. season; however, we only present the results of the last rating. Differences in disease rating by location were also found (Table 1), with the overall disease ratings being higher at Khon Kaen compared with Kamphaeng Saen (Fig. 1). The differences in entry symptom severity between locations highlights the importance of multilocation testing for disease resistance.

While no entry was immune to the disease, we identified one highly resistant breeding line, 9853-123, with an average rating of 1.6 at Khon Kaen and 1.1 at Kamphaeng Saen at 120 dpi (Fig. 1). Several other entries were moderately resistant, although there was a high level of variability in their disease reactions (Fig. 1). The entries PBC 186, PBC 518, PBC 581, PBC 1565, and PI 171555 had high average disease ratings at $120 \mathrm{dpi}$; however, we also found a large range in their scores, with some individual plants scoring near 1, or resistant (Fig. 1). This is evidence that these lines might be segregating for resistance and selection followed by selfpollination could be imposed to increase the resistance level of these entries.

The previously published resistant lines PBC 142, PBC 143, PBC 145, PBC 148, PBC 149, PBC 495 (Kenyon et al., 2014a; Srivastava et al., 2015, 2017) were not resistant in our study (Table 2). The reasons for these differences could be attributable to the use of different species of Begomovirus, with Tomato yellow leaf curl Thailand virus was used in Taiwan (Kenyon et al., 2014a) and Chili leaf curl virus (ChiLCV), Tomato leaf curl Joydebpur virus (ToLCJoV) (monopartite), and Tomato leaf curl New Delhi virus under open field conditions were used in India (Srivastava et al., 2015, 2017). The differences could also be due to inoculation techniques used (viruliferous whitefly or natural field inoculation) or because we scored at $120 \mathrm{dpi}$ and not at the seedling stage. Genetic recombination, the acquisition of extra DNA components, and the synergistic interaction among different begomoviruses has resulted in the rapid emergence of new viruses that can infect new hosts, cause new disease symptoms, and overcome host resistance (Chakraborty et al., 2003; Singh et al., 2016; Varma and Malathi, 2003).

None of the entries belonging to the other domesticated or wild Capsicum species were resistant, and some of the most susceptible entries evaluated here included PI 159236, VI012642, and VI012271 (C. chinense), VI012528 (C. baccatum), and PI 574547 (C. annuum var. glabriusculum) (Fig. 1). Although a member of $C$. chinense, the accession VI012271, as well as the C. annuum accession VI012911, have the potential to be used as susceptible checks in future studies because they displayed a consistent and high disease rating at both locations (Fig. 1).

Jabłońska-Sabuka et al. (2015) found that intensive farming and breeding partially resistant cultivars were the major triggers for aggressive Begomovirus adaptability through mutation speed-up. Therefore, it would be 
Table 2. Average disease rating of previously identified sources of Begomovirus resistance at two locations in Thailand scored at $120 \mathrm{~d}$ postinoculation with Pepper yellow leaf curl Thailand virus.

\begin{tabular}{lcc}
\hline Entry & Khon Kaen & Kamphaeng Saen \\
\hline PBC 142 & $4.1^{\mathrm{z}}$ & 3.9 \\
PBC 143 & 6.0 & 3.7 \\
PBC 145 & 3.7 & 4.6 \\
PBC 148 & 3.2 & 3.6 \\
PBC 149 & 3.7 & 3.3 \\
PBC 495 & 4.0 & 4.4 \\
\hline
\end{tabular}

${ }^{\mathrm{z}} \mathrm{A}$ standardized six-point scale modified from Sangsotkaew et al. (2019) (1= no symptoms; $2=$ very mild symptoms with slight yellowing only occurring near the petiole of young leaves; $3=$ mild symptoms of slight yellowing of the entire area of young leaves; $4=$ moderate symptoms of dark yellowing of young leaves and some old leaves; 5 = severe symptoms of dark yellowing of young and most of the old leaves; $6=$ very severe symptoms of complete plant yellowing, stunting, and lack of flower set) was used for evaluation.

beneficial to use an integrated pest management (IPM) approach that combines resistant cultivars (potentially multiline cultivars) with different whitefly and viral control measures. It has been estimated that farmers who adopt minimal, moderate, and highly integrated management strategies for Begomovirus could improve incomes by $17 \%, 26 \%$, and $80 \%$, respectively (Swaminathan et al., 2016). Using Begomovirus-specific primers, the DNAA and DNA-B of PepYLCThV were amplified and sequenced from both asymptomatic and symptomatic plants of 9853-123 (99.3\% identity for DNA-A and $98.1 \%$ identity for DNAB). The ability of the virus to colonize the plant, but the overall lack of severe symptoms indicates a recognition mechanism exists in 9853-123, and the low disease rating was not the result of the plants being missed during inoculation. This provides a basis for future inheritance studies as well as quantitative trait locus analysis and downstream resistance gene identification.

\section{Literature Cited}

Adluri, P.K., G.M. Baldoldiya, and P.D. Nath. 2017. Screening of Bhut Jolokia (Capsicum chinense Jacq.) germplasm of North East India against chili leaf curl virus. Intl. J. Pure Appl. Bioscience 5:1189-1196.

Anaya-Lopez, J.L., I. Torres-Pacheco, M. Gonzalez-Chavira, J.A. Garzon-Tiznado, J.L. Pons-
Hernandez, R.G. Guevara-Gonzalez, C.I Muñoz-Sánchez, L. Guevara-Olvera, R.F Rivera-Bustamante, and S. Hernández-Verdugo. 2003. Resistance to Geminivirus mixed infections in Mexican wild peppers. HortScience 38:251255.

Borah, B.K. and I. Dasgupta. 2012. Begomovirus research in India: A critical appraisal and the way ahead. J. Biosci. 37:791-806.

Chakraborty, S., P.K. Pandey, M.K. Banerjee, G. Kalloo, and C.M. Fauquet. 2003. Tomato leaf curl Gujarat virus: A new Begomovirus species causing severe leaf curl disease of tomato in Varanasi, India. Phytopathology 93:14851495.

Chiemsombat, P., B. Srikamphung, and S. Yule. 2018. Begomoviruses associated to pepper yellow leaf curl disease in Thailand. J. Agr. Res. 3(7):000183, doi: 10.23880/oajar-16000183.

DeWitt, D. and P.W. Bosland. 1993. The pepper garden. Ten Speed Press, Berkeley, CA.

Food and Agriculture Organization of the United Nations (FAO). 2016. FAOSTAT statistics database. Food and Agriculture Organization, Rome, Italy.

Halikowski-Smith, S.H. 2015. In the shadow of a pepper-centric historiography: Understanding the global diffusion of Capsicums in the sixteenth and seventeenth centuries. J. Ethnopharmacol. 167:64-77.

Jabłońska-Sabuka, M., R. Kalaria, and T. Kauranne. 2015. A dynamical model for epidemic outbursts by Begomovirus population clusters. Ecol. Modell. 297:60-68.

Kahane, R., T. Hodgkin, H. Jaenicke, C. Hoogendoorn, M. Hermann, J.D.H. Keatinge, J. d'Arros Hughes, S. Padulosi, and N. Looney. 2013. Agrobiodiversity for food security, health, and income. Agron. Sustain. Dev. 4:671-693.

Kenyon, L., S. Kumar, W.S. Tsai, and J. d'A. Hughes. 2014a. Virus diseases of peppers (Capsicum spp.) and their control, p. 297354. In: G. Loebenstein and N. Katis (eds.). Control of plant virus diseases. Vol. 90. Advances in virus research. Academic Press, San Diego, CA.

Kenyon, L., S.L. Shih, L.M. Lee, and Y.L. Chan. 2018. Diversity of begomoviruses causing disease in peppers (Capsicum spp.) in Asia. Phytopathology 108(S1):99 (abstr.).

Kenyon, L., W.S. Tsai, S.L. Shih, and L.M. Lee. 2014b. Emergence and diversity of begomoviruses infecting solanaceous crops in East and Southeast Asia. Virus Res. 168:104-113.

Kumar, S., S. Kumar, M. Singh, A.K. Singh, and M. Rai. 2006. Identification of host plant resistance to pepper leaf curl virus in chilli (Capsicum species). Scientia Hort. 110:359361 .
Pernezny, K.L., P.D. Roberts, J.F. Murphy, and N.P. Goldberg. 2003. Compendium of pepper diseases. APS Press, St. Paul, MN.

Samretwanich, K., P. Chiemsombat, K. Kittipakorn, and M. Ikegami. 2000. A new Geminivirus associated with a yellow leaf curl disease of pepper in Thailand. Plant Dis. 84(9):1047 (abstr.).

Sangsotkaew, Y., N. Jeeartid, N. Siri, P. Thummabenjapone, O. Chatchawankanphanich, B. Phuangrat, and S. Techawongstien. 2019. Phenotypic responses of putative resistance chili cultivars infected by PepYLCV with viruliferous whitefly transmission. Acta Hort. (In press.)

Shankarappa, K., S. Sriharsha, K.T. Rangaswamy, D.S. Aswathanarayana, H.A. Prameela, R.S. Kulkarni, V. Muniyappa, A.M. Rao, and M.N. Marauthi. 2008. Development of tomato hybrids resistant to tomato leaf curl virus disease in South India. Euphytica 164:531-539.

Singh, A.K., N. Kushwaha, and S. Chakraborty. 2016. Synergistic interaction among begomoviruses leads to suppression of host defenserelated gene expression and breakdown of resistance in chilli. Appl. Microbiol. Biotechnol. 100:4035-4049.

Srivastava, A., M. Mangal, R.K. Saritha, L.J. Santosh, G. Uttamgir Gosavy, and P. Kalia. 2015. Natural epiphytotic screening of chilli germplasm lines against leaf curl virus complex. Intl. J. Trop. Agr. 33:3581-3586.

Srivastava, A., M. Mangal, R.K. Saritha, and P. Kalia. 2017. Screening of chilli pepper (Capscium spp.) lines for resistance to the Begomovirus causing chili leaf curl disease in India. Crop Prot. 100:177-185

Swaminathan, B., K.C. Siva Balan, N. Anadaraja, N. Manikanda Boopathi, P. Schreinemachers, R. Srinivasan, and M.H. Wu. 2016. Profitability of Begomovirus management strategies among chilli farmers in Tamil Nadu: A gross margin impact analysis. Indian J. Agr. Res. 50:159-166.

Tsai, W.S., S.L. Shih, L. Kenyon, S.K. Green, and F.J. Jan. 2011. Temporal distribution and pathogenicity of the predominant tomato-infecting begomoviruses in Taiwan. Plant Pathol. 60:787799.

Varma, A. and V.G. Malathi. 2003. Emerging Geminivirus problems: A serious threat to crop production. Ann. Appl. Biol. 142:145-164.

Wall, M.M. and P.W. Bosland. 1998. Analytical methods for color and pungency of chiles (Capsicums), p. 347-373. In: D. Wetzel and G. Charalambous (eds.). Instrumental methods in food and beverage analysis. Elsevier, Amsterdam, the Netherlands.

Weinberger, K. and T.A. Lumpkin. 2007. Diversification into horticulture and poverty reduction: A research agenda. World Dev. 35:1464-1480. 